\title{
TECHNICAL REVIEW OF RRD-RED-930373 CRITICALITY SAFETY EVALUATION FOR L AREA DISASSEMBLY BASIN CLEANUP (U)
}

by

\author{
R. L. Reed
}

Savannah River Site

Aiken, South Carolina 29808

\section{DISCLAIMER}

\begin{abstract}
This report was prepared as an account of work sponsored by an agency of the United States Government. Neither the United States Government nor any agency thereof, nor any of their employees, makes any warranty, express or implied, or assumes any legal liability or responsibility for the accuracy, completeness, or usefulness of any information, apparatus, product, or process disclosed, or represents that its use would not infringe privately owned rights. Reference herein to any specific commercial product, process, or service by trade name, trademark, manufacturer, or otherwise does not necessarily constitute or imply its endorsement, recommendation, or favoring by the United States Government or any agency thereof. The views and opinions of authors expressed herein do not necessarily state or reflect those of the United States Government or any agency thereof.
\end{abstract}

DOE Contract No. DE-AC09-89SR18035

This paper was prepared in connection with work done under the above contract number with the U. S.

Department of Energy. By acceptance of this paper, the publisher and/or recipient acknowledges the U. S. Government's right to retain a nonexclusive, royalty-free license in and to any copyright covering this paper, along with the right to reproduce and to authorize others to reproduce all or part of the copyrighted paper.

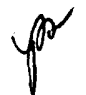




\section{DISCLAIMER}

This report was prepared as an account of work sponsored by an agency of the United States Government. Neither the United States Government nor any agency thereof, nor any of their employees, makes any warranty, express or implied, or assumes any legal liability or responsibility for the accuracy, completeness, or usefulness of any information, apparatus, product, or process disclosed, or represents that its use would not infringe privately owned rights. Reference herein to any specific commercial product, process, or service by trade name, trademark, manufacturer, or otherwise does not necessarily constitute or imply its endorsement, recommendation, or favoring by the United States Government or any agency thereof. The views and opinions of authors expressed herein do not necessarily state or reflect those of the United States Government or any agency thereof.

This report has been reproduced directly from the best available copy.

Available to DOE and DOE contractors from the Office of Scientific and Technical Information, P. O. Box 62, Oak Ridge, TN 37831; prices available from (615) $576-8401$.

Available to the public from the National Technical Information Service, U. S. Department of Commerce, 5285 Port Royal Rd., Springfield, VA 22161 


\section{Applied Technology Section Applied Physics Group}

October 1, 1993

UNCLASSIFIED

DOES NOT CONTAIN UNCLASSIFIED CONTROLLED NUCLEAR INFORMATION

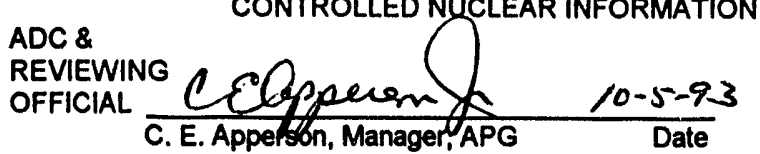

KEYWORDS:

Reactors

Technical

Disassembly Area

Criticality

RETENTION:

PERMANENT

\section{TECHNICAL REVIEW OF RRD-RED-930373} CRITICALITY SAFETY EVALUATION FOR L AREA DISASSEMBLY BASIN CLEANUP (U)

Author

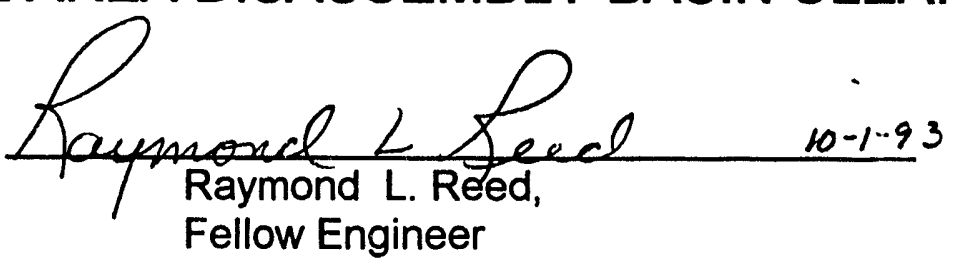

APPROVALS

Task Leader

APG Criticality Methods and Analysis

Manager

Applied Physics Group (APG)

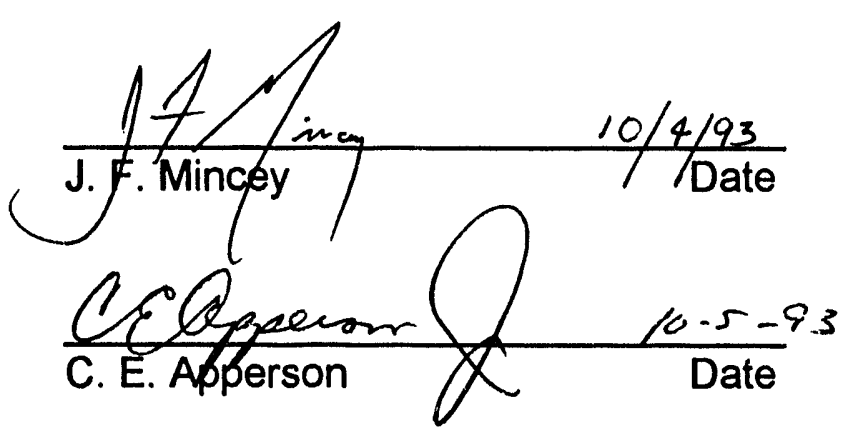

Distribution:

F. Beranek,

M. R. Buckner,

C. E. Apperson,

J. F. Mincey,

M. A. Rosser

R. L. Reed,

Technical Information Management, 703-43A

$773-A$
$773-A$
$773-42 A$
$773-22 A$
$705-K$
$773-42 A$

R. L. Webb,

E. F. Trumble,

T. G. Williamson,

P. L. Vescovi,

R. E. Rathbun,

APG Files,
786-1A

786-1A

773-42A

773-22A

786-1A

$773-42 A$ 


\section{INTRODUCTION}

The study documented in RRD-RED-930373 (Reference 1) performed an evaluation of the criticality potential associated with sludge removal from the Disassembly Basin to the Monitor Basin of L Area Disassembly. The concern was that sufficient fissionable material has been released into the basin (and is now intermixed in the sludge) that the process of removing the sludge can cause the fissionable material to be formed into a critical configuration. The evaluation employed results of analytical measurements of the sludge composition to estimate the total amount of fissile material in the basin and provided comparisons of those fissile masses with accepted standard safe subcritical mass limits for each fissile component to demonstrate that the fissionable material isotopic composition of the sludge can not be formed into a critical configuration.

The analysis demonstrated that the fissile material content of the L Disassembly Basin is insufficient to form a critical mass, even with optimum geometry and concentration.

RRD-RED-930373 used the same methodology and arguments as previously reviewed in RRD-RED-930306 (References 2 and 3). The review was performed per QAP II-14 of 1Q34 (References 4 and 5).

\section{DISCUSSION}

This review emphasized the adequacy of the approaches and approximations used for the study and verification of agreement between the analytical data used in the fissile mass estimate process and the reported analytical data. The analytical data used for the estimates were also reviewed for internal consistency and reasonableness.

The review was performed before the analytical results had been formally reported in a documented analysis, but the analytical results were informally transmitted from the analyst to Rosser to expedite Rosser's work. No changes are expected in the results during that documentation process. If changes occur, Rosser will provide needed adjustments before issuing his report, with additional review, as needed, by APG personnel, before APG signature approval is granted.

The review consisted of

- a careful reading of the draft document, reference documents, and the author's notebook in which the calculations converting the analytical sludge material compositions to total masses in the basins were recorded,

- examination of consistency of numerical values reported in the draft document with data provided in reference documents,

- examination of the relative data values of the analytical results to verify the composition data are reasonable and consistent, and

- discussion with the author of minor editorial comments. 
Separate, independent calculations were not performed since all calculations were essentially repetitive conversions of the analytical data reported by SRTC-ADS from isotopic wt \% values in sludge to grams fissile material (each isotope) in the basins and comparisons by Rule of Fractions as provided in ANSI/ANS-8.15-1981) to safe subcritical limits specified in the ANS standards. The conversions and comparisons were reviewed (with numerous spot recalculations) and determined to be accurate. The volume-to-mass conversions for the sludge volumes and masses in each basin were reviewed, including explicit dimensional verifications from the referenced drawings. The estimated volumes stated were cross-checked against a value for the overall Disassembly Basin dimensions. No computer code calculations were employed by the author or reviewer.

No technical comments were noted. None were expected since the methodology duplicates that in a similar previously reviewed study (References 2 and 3). Only fissile isotopes were considered in the evaluation since the sludge material is in a very aqueous state. Several editoria! comments were verbally discussed with the author. Those comments recommendea that embedded tables in the text be placed in a column format for easier reading and suggested minor wording improvements.

It was suggested to the author that the hand calculations be placed on a spreadsheet since several such more analyses will be required during different phases of the sludge removal from all areas. A spreadsheet calculation can also be readily updated if transcribing errors or inaccurate values are noted. Verifications of such hand calculations can also be easily done since all numbers inputted are part of the spreadsheet and can be printed and saved in logbooks for record purposes.

\section{SUMMARY AND CONCLUSIONS}

The study presents a good evaluation of the criticality potential associated with the sludge removal process in L Disassembly Basin. Even with a large degree of conservatism employed in the evaluation, the analysis shows that the total fissile mass in the basin is less than a critical mass. The conservative factors have been welldelineated and the degree of conservatism has been assessed. Appropriate conservative actions are recommended and should be implemented:

- Verification of NIM operability prior to and during the sludge removal operation,

- Prohibition of fissile component movement during the sludge removal operation, and

- Measurement of sludge composition after the sludge transfer to the monitor basin. 


\section{REFERENCES}

1. M. A. Rosser, "CRITICALITY EVALUATION FOR L AREA DISASSEMBLY BASIN CLEANUP (U)", RRD-RED-930373, September 29, 1993 (DRAFT) (See Attachment 2)

2. M. A. Rosser, "CRITICALITY EVALUATION FOR K AREA DISASSEMBLY VTS CLEANUP (U)", RRD-RED-930306, August 18, 1993

3. R. L. Reed, "TECHNICAL REVIEW OF RRD-RED-930306 NUCLEAR CRITICALITY SAFETY EVALUATION FOR K AREA DISASSEMBLY VTS CLEANUP (U)", SRT-SMA-930049, August 17. 1993

4. MANUAL 1Q34, NRTSC QUALITY ASSURANCE MANUAL, January 1991

5. NRTSC QA Procedure QAP II-14, "TECHNICAL REVIEW", August, 1991 
OSR 24-K7

NRTSC REVIEW SHEET

TASK TITLE NCSE FOR LAREA DISASSEMBLY BASIN CLEANUP

TASK NUMBER_ N/A

ITEM REVIEWED RRD-RED-930373

(Attach additional pages as necessary; marked-up pages are acceptable.)

PAGE 1 OF 1

\section{Areas reviewed (identify clearly each area reviewed).}

Logic of presentation

Clarity of presentation

Accuracy of presentation

Applicability of presentation

Consistency of data values referenced to reference values

\section{Approaches used to perform the review.}

Read the document carefully.

Read the references carefully and ensured data values were accurately repeated.

Checked the hand calculations reported and verified their accuarcy.

Ensured the readability of the presentation and agreement of intent with material as presented.

Discussed minor editorial preferences with author

3. Questions, comments to be resolved.

Before issue of RRD-RED-930373, verify that analytical results used in RRD-RED-930373 are same as those in ADS analyst's final report.

$\underline{X}$ l agree with the technical content I disagree with the technical content.

$\mathrm{X}$ I accept the conclusions and recommendations

I do not accept the conclusions and recommendations for the following reasons:

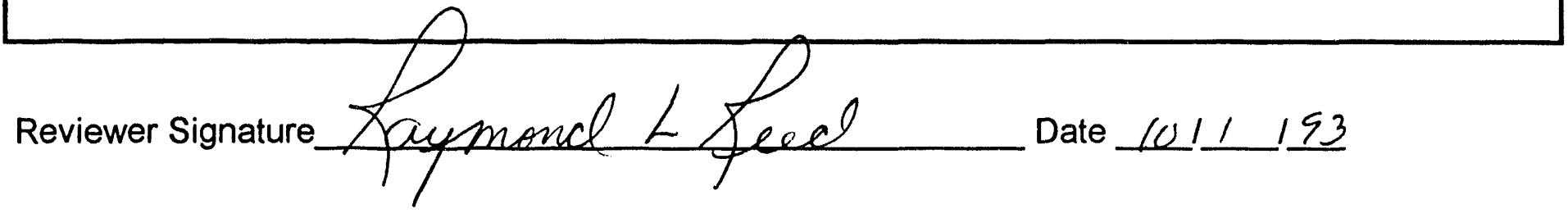


1):11

RRD-RED-930373

$$
\begin{aligned}
& \text { (n) }
\end{aligned}
$$

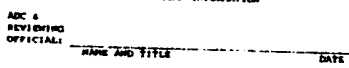

September 29, 1993

\section{To: S. D. Burke, 707-C}

FROM: M. A. Rosser, 705-K

SRTC Technical Reviewer:

$$
\begin{aligned}
& \text { D. B. Rankin, 704-c } \\
& \text { S. R. Smith, 705-K } \\
& \text { R. H. Deible, 707-C } \\
& \text { H. R. Lindenberger, 707- } C \\
& \text { R. R. Leed, 773-42A } \\
& \text { D. R. Shelton, 707-C }
\end{aligned}
$$

CRITICALITY SAFETY EVALUATION FOR L AREA DISASSEYBLY BASIN CLEANUP IUI INTRODUCTION

Preparations are currently being made to remove sludge from the Disassembly Basin in all reactor areas. Because this sludge contains
fissile 1sotopes (Reference 1). It is necessary to perform a evaluations examined the criticality safety aspects of the Previous document addresses the criticality (References 2 and 3 ). This disassembly basin cleanup work.

The 2 Area disassembly basin cleanup will Involve, as a flrst step, Basin, the sludge will be pumped into itor Basin. From the Monito permanent disposition. The criticality safery ovaluation disers for future transfers of the transfer of the sludge to the Monitor Basin. analyses and may require additional criticalidy sanal material sampie SUMMARY

The total mass of fissile material that could be present in the
Monitor Basin as a result of the transfer of sludge from the $L$ area
RRD-RED-9.303\%3

Page 2
September 29, 1993

disassembly basin is less than that required to attain a critical
configuration. Thus, there are required for the $L$ Area disassembly basin sludge removal process thit

orscussion

An sccumulation of sludge 15 present on the floor of the $L$ Ares basin to determine the composition of or lisotopes that are of concern for criticality safety evaluatrions of interest for this ICP/MS spectrometry (Reference 1). The 1sotopes support a slow neutron chain reaction) the arde lsotopes 11.e.- can The concentrations of interest, representing the most in the sludge. of grams/gram estimate the sludge density as app 1) Th-additionr SRTC analysts centimeter (Reference 10).

Datermination of Isotope masses

Having determined the concentrations of the 1sotopes of interest for this criticality safety evaluation, the next step is to determine the
mass of each 1sotope. To do this, an estimate of the amount of sludge
present is needed. disassembly basin drawings timensions provided in various

* of 3 inches (Reference 51 . the following values were determined for f the assumed volume of sludge present in each area of the basin:

I. VTS (Includes DKE Canal) (Drawlngs M132078, M132079, M132025 and

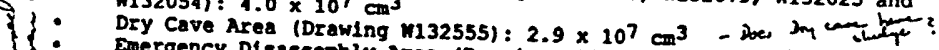
Monitor Basin (Drauly Area (Drawling 1132548 ): $1.2 \times 10^{7} \mathrm{~cm}^{3}$ Machine Area (Drawing W132448): $: 4.5 \times 10^{6} \mathrm{~cm}^{3}$

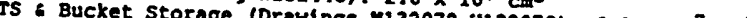
ransfer Bay P1t 11 and P1t $\$ 2$ (Drawing W16951: $: 6.0 \times 10^{7} \mathrm{~cm}^{3}$ The above volumes represent conservative estimates since only overall
basin dimensions were used and no consideration was given to the
amount of basin floor space covered by structural a

From the volume of sludge calculated above, one can then determine the disassembly basin, for this criticality safety each area of the density of 1.01 g/ce, the total mass of sludge for each section of the
basin is as follows: 
RHD-RED-930373

Page 3 3 September 29, 1993
Septos

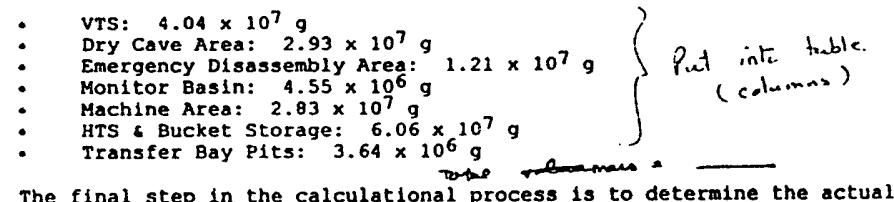
mass estimates of the isotopes that are of concern for criticality safety evaluations. This is accomplished by multiplying the total
sludge mass by the concentration of the isotopes, in each section of sumned. This results in the total mass of each isotope present in the Monitor Basin after all sludge has been removed from the disassembly

Criticality Safety Evaluation

The 1sotope masses calculated above must now be compared with the applicable limits to ensure subcriticallty and, thus, criticality safety. The llatts used in this published in accepted eriticality safety references (References 6,7 and 8 ). The subcritical 1imits of particular interest to this evaluation are given in Table 3 .

Because the sludge contains a mixture of fissile 1sotopes, criticality safety evaluations must go beyond a simple comparison with the applicable 1ndividual 11 mits. The criticallty potential of the mixture as a whole must be considered. American National standard
(ANS) - $8.15-1981$ (Reference 6) provides guidance on performing these types of mixture analyses. This standard states that the subcritical 1 imits may be applied to mixtures of ilssile nuclides provided the sum of the ratios of the mass of each fissile nuclide to 1 ts 1 imit does not exceed unity. In other words, divide the mass of each 1sotope by greater than 1 , there 13 a high confidence that the mixture will

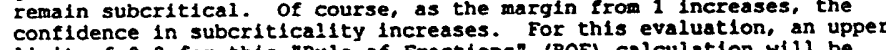
limit of 0.9 for this "Rule of Fractions (Ros calculation used to deciare that a mas uncertainties in the RoF methodolog (Reference 9).

Prior to a discussion of the ROF results for this evaluation, two clarifications are in order. First of all, according to keference 6 , mixtures. This requtrement is satisfied for this evaluation. If one considers the sludge sample density and composition analyses, one can
RRD-RED-930373

Page 4-
September 29, 1993

then use this fact to determine that the hydrogen-to-fissile atom ratio 1s greater than $10^{7}$. Th1s more than qualifies as a wellmoderated mixture, and, since the hydrogen appears primarily in the
form of water, the description of this sludge as an aqueous mixture is also appropriate.

The second clarification involves the isotopes (and assoclated Reference 6 implies that uranium isotopes may not be used with the Ror methodology. It is generally accepted that this implied exclusion of uranium 1sotopes is not consistent with the actual intento of a ROF evaluation that includes U-235. As a result, this evaluation assumes that it is acceptable to include uranium 1sotopes in ROF calculations.

The above ROF methodology was applled to the calculated masses given in Table 2 . The resulting "sum of the ratios" produced a value of
0.28 . This value is much less than the subcritical guideline of 0.9 and, thus, lndicates that the mixture 1s signiricantly suberitical because of insulficlent the syste even more subcritical. This result means that the $\mathrm{L}$ Area cleanup process has an even greater subcritical margin than that

Consideration of Uncertalntios

\section{The primary sources of uncertalnty in this analysis are the}

measurement uncertalinty assochated with the sample results and the uncertal The celculations discussed above were repeated assuming conservative measurement uncertainty (Roference 1 ) and aximum sludge depth of 6 inches (Reference 5). Isotope masses were calculated assuming that fissile lsotope concentrations increased by concentration (the effects of which are discussed below) was decreased by the same percentage. It is assumed that the uncertainties in Reference 1 correspond to 1-slgas uncertaln the un Under thes 1 assumption, using the adjustments to the other 1sotopes.

The Rule of Fractions calculation for the above conditions produced of subcriticality. In addition, there are several favorable aspects
that were not inciuded in this evaluation which will further increase the suberitical margin

- The presence of U-238 in the sludge was neglected. U-238 in the
sludge serves as a neutron poison and will effectively increase the

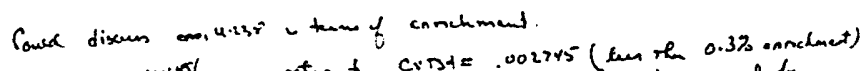

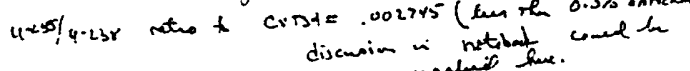


RRD-KED-930373

Page 5
September 29, 1993

subcritical mass 11 mit of the fissile 1sotopes. As an example, including the $0-238$ mass dice U-235 subcritical mass $11 \mathrm{mit}$ alone and represents a significant increase in subcritical margin.

- The sludge contains iron (10-24 wt of solids). The primary stable iron isotopes have thermal neutron capture cross sections that range from $2.5 \mathrm{~b}$ to $2.8 \mathrm{~b}$. This is similar to the $2.7 \mathrm{~b}$ cross section of U-238. The effects of the presence oresent in the sludge, we have an additional neutron poison that was not considered in this evaluation.

- The ICP/MS concentrations, where applicable, were assumed to other, non-fissile 1 sotopes was ignored. The Am-242m concentration is a prime example of the conservatism introduced by this action. The possible presence of pu-242 should be the primary weight 242 isotope in the sludge. In the abcve ROF calculation that includes uncertainties, Am-242m

- As discussed earlier, the sludge depth $1 \mathrm{~s}$ not 6 Inches everywhere and in addition, the calculation of sludge mass ignored the fact that some floor space in the disassembly basin is taken up by concrete supports. I his would lead to a salculated values for of total sludge mass resil
fissile 1 sotope masses.

- The most conservative disassembly basin fissile isotope ncrease in concentrations of certain 1 sotopes vary by a factor of or more.

- The actual concentrations of the fissile isotopes in the sludge are $\mathrm{cm}^{3}$, or 17 ion equivalent U-235 mass, the result is $504 \mathrm{~g}$. This corresponds to a concentration of $0.003 \mathrm{~g} / 11$ ter. Table 2.1 of Reference 7 gives a subcrltical concentraten would have to concentrate by more than 3 orders of magnitude to
achieve this concentration. There is presently no mechanism
MHD-PEV -930373

Page 6
September 29, 1993

identified by which the U-235, or any of the other 1sotopes, could separate fro
this manner.

concuusion

The total mass of fissile material that could be present in the Monitor Basin after the cleanup of sludge in the As a result, there are no criticality safety operating limlts required for this process. After the sludge has settled in the Monitor Basin, and prior to the transfer of the sludge from the Monitor Basin to permanent disposition, additional sludge compusition that would performed to verify that no
invalidate this evaluation.

As a final comment, since the sludge removal process involves the Avement of flssile 1sotopes, NIM operabllity must be verified and the movement of other components containing fiss
suspended during the sludge movement process.

REFERENCES

1. Tovo, L. L., ... torme repot to the efferemenc heere

2. Rosser, M. A., "Criticality Safety Evaluation for K Area
Disassembiy vTS Cleanup (U) $\%$, RRD-RED-930306, August 18, 1993.

. Reed $R$. "Criticality constderation

Rludge (U)", RRD-RTS-930020, January 25, 1993.

4. Gibbs, A., "Disassembly Basin Sludge Characterization Analyses 3, 1993.

5. Stokes, M. M., "Re: Criticality Memo", SRT-EES-930105, June 2, 1993.

6. "American National Standard for Nuclear Criticality Control of
Special Actinide Elements," ANS-8.15-1981, November 9, 1981.

7. Nuclear Safety Guide, TID-7016, Revision 2, NUREG/CR-0095, June

8. "American National Standard for Nuclear Criticality Safety in 1983, October 7, 1983 .

9. Finch, D. R. and Hilliamson, T. G., "Validity of the Rule-ofFractions for Assurting Criticallty safe 
RRD-RED-930373

September 29, 1993

10. Tovo, L. L.. "Results of $K$ Area Vertical Tube Storage Basin Sludge

11. Drawling 1 W132078, Revision 68 .

12. Drawing "W132079, Revi-ion 17.

13. Drawing "w132025, Revision 24.

14. Drawing NW132054, Revision 16.

15. Drawing "W132448.

] Revison " (emif Rue

16. Drawing "W132555, Revision 43.

17. Drawing NW132548, Revision 15.

18. Drawing "W132459, Revision 17.

19. Drawing "w169514, Revision 25.

KEYWORDS

Reactors
Criticality
Disassembly
RRD-RED-930373

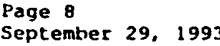

TABLE

BASIN ISOTOPE CONCENTRATIONS (g/g Of SAmple)

- VTS + DGE Canal

$\begin{array}{ccc}\text { ISOTOPE } & \text { CONCENTRATION }(g / g) & \text { DETERMINED BY } \\ \text { U-233 } & 1.01 \times 10^{-8} & \text { ICP/MS } \\ \text { U-235 } & 2.91 \times 10^{-7} & \text { ICP/MS } \\ \text { PU-239 } & 5.92 \times 10^{-8} & \text { ICP/MS } \\ \text { PU-241 } & 2.62 \times 10^{-9} & \text { ICP/MS } \\ \text { Am-242m } & 3.55 \times 10^{-9} & \text { ICP/MS } \\ \text { Cm-243 } & 1.25 \times 10^{-9} & \text { ICP/MS }\end{array}$

- Machine Basin IIncludes Dry Cave, Emergency Disassembly, Monitor

asin, Machine Area and HTS/Bucket Storage)

\begin{tabular}{ccc} 
ISOTOPE & CONCENTRATION $(g / g)$ & DETERMINED BY \\
\cline { 2 - 3 } U-233 & $9.16 \times 10^{-9}$ & ICP/MS \\
U-235 & $8.25 \times 10^{-7}$ & ICP/MS \\
PU-239 & $1.11 \times 10^{-7}$ & ICP/MS \\
PU-241 & $1.80 \times 10^{-9}$ & ICP/MS \\
Am-242m & $3.89 \times 10^{-9}$ & ICP $/ M S$ \\
CM-243 & $2.81 \times 10^{-9}$ & ICP/MS
\end{tabular}

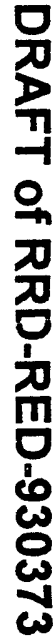

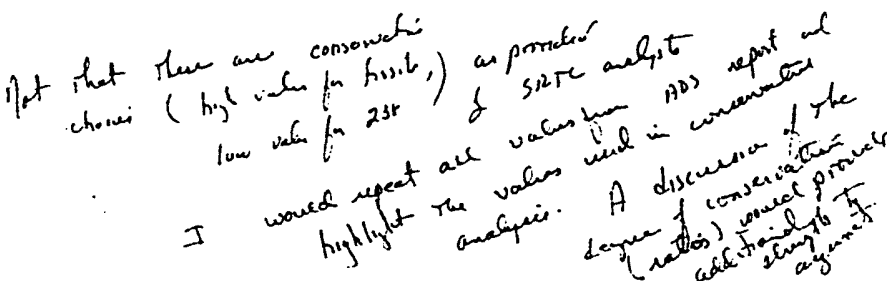


TABLE 1 (cont.)

KRIJ-KE:D-Y.30373
Page 10

BASIN ISOTOPE CONCENTRATIONS $19 / 9$ Of sample) - Transfer Bay

\begin{tabular}{ccc} 
ISOTOPE & CONCENTRATION $(g / g)$ & DETERMINED BY \\
\cline { 1 - 2 } U-233 & $7.83 \times 10^{-9}$ & ICP/MS \\
U-235 & $6.19 \times 10^{-7}$ & ICP/MS \\
PU-239 & $1.11 \times 10^{-7}$ & ICP/MS \\
PU-241 & $9.53 \times 10^{-9}$ & ICP/MS \\
Am-242m & $2.32 \times 10^{-9}$ & ICP/MS \\
Cm-243 & $1.67 \times 10^{-9}$ & ICP/MS
\end{tabular}

Page 11
September 29, 1993

TABLE 3

MINIMUM SUBCRITICAL MASS LIMITS FOR VARIOUS ISOTOPES

\begin{tabular}{ccc} 
ISOTOPE & SUBCRIT. MASS LIMIT & REFERENCE NOTES \\
\cline { 1 - 2 } U-233 & $500 \mathrm{~g}$ & A \\
$\mathrm{U}-235$ & $700 \mathrm{~g}$ & A \\
Pu-239 & $450 \mathrm{~g}$ & A \\
Pu-241 & $200 \mathrm{~g}$ & B \\
Am-242m & $13 \mathrm{~g}$ & B \\
$\mathrm{Cm}-243$ & $90 \mathrm{~g}$ & $\mathrm{~B}$
\end{tabular}

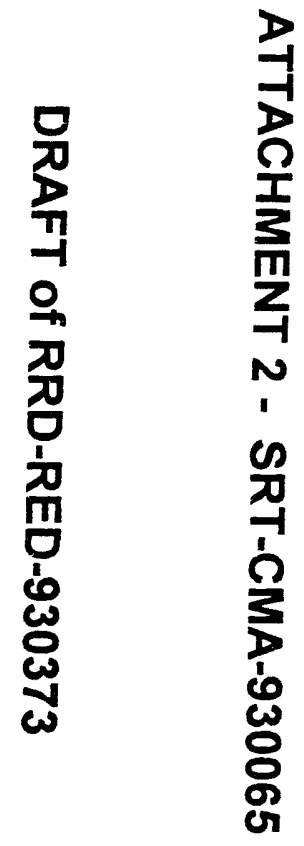

Reference Notes:

A. See Section 5.2 of Reference 8 .

B. See Table 2 of Reference 6 .

\begin{tabular}{cc} 
ISOTOPE & 2AASS (g) \\
\cline { 2 - 2 } U-233 & 1.6 \\
U-235 & 125.5 \\
PU-239 & 17.8 \\
Pu-241 & 0.3 \\
Am-242m & 0.6 \\
Cm-243 & 0.5
\end{tabular}

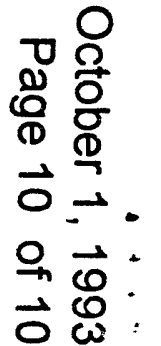

